\title{
issent and Conformism: Individual Posture and Search for Universal Criteria - Possibilities of Choice
}

\section{Gintaras Druckus}

Kaunas Regional State Archives, E-mail: g.druckus@archyvai.lt

\begin{abstract}
The aim of the report is to introduce the author's point of view concerning the dilemma between dissent and conformism based on Lithuanian investigations and archival documents. The prevailing chronological frames are defined by the fifth decade of the twentieth century up to second decade of the twenty-first century. The report seeks to answer the following questions:

1) is it possible to define universal criteria for dissent and conformism investigation? Is it possible to draw a clear line between such converging meanings as resistance and dissent, dissent and conformism, conformism and obedience, conformism and surrender, conformism and betrayal, conformism and selfsacrifice? Do such dividing lines exist at all?

2) what kind of category dissent and conformism are - legal or moral? In case their nature is legal - then first of all we should talk about (dis)obedience to certain legislative norms and qualify certain activities or stand in the light of law. In case their nature is moral then we have the case of individual or collective choice in between human values.

Though in Lithuania like in a number of other occupied countries dissent and conformism are directly related both: to individual freedom as well to nation and state independence aspirations, the nature of these phenomena lies

\section{Rezumat}

Scopul acestei analize îl reprezintă elaborarea punctului de vedere al autorului cu privire la dilema disidență versus conformism pe baza investigațiilor lituaniene și a documentelor de arhivă. Cadrele cronologice predominante sunt definite de deceniul al cincilea al secolului al XX-lea și al doilea deceniu al secolului al XXIlea. Raportul urmărește să răspundă la următoarele întrebări:

1) Este posibil să se definească criterii universale pentru investigarea disidenței și conformismului? Este posibil să se stabilească o linie clară între semnificații atât de convergente precum rezistența și disidența, disensiunea și conformismul, conformismul și supunerea, conformismul și predarea, conformismul și trădarea, conformismul și sacrificiul de sine?

Există astfel de linii de diviziune?

2) ce fel de categorii sunt disidența și conformismul - juridice sau morale? În cazul în care natura lor este legală, atunci în primul rând ar trebui să vorbim despre (ne) ascultarea de anumite norme legislative, despre o anumită perspectivă asupra unor anumite activități sau despre supunerea în fața legii. In cazul în care natura lor este morală - atunci avem cazul alegerii individuale sau colective între valorile umane.

Deși în Lituania, ca și în alte țări ocupate, disidența și conformismul sunt direct legate
\end{abstract}


in the person and his or her personal relationship with the values. Such a choice should be treated like an inevitable existential exam to every human generation, to each of us. atât de libertatea individuală, cât și de aspirațiile de independență ale națiunii și ale statului, natura acestor fenomene constă în persoana și relația sa personală cu valorile. $O$ astfel de alegere ar trebui tratată ca un examen existențial inevitabil pentru fiecare generație umană, pentru fiecare dintre noi.

Keywords: Dissent; Conformism; Lithuania;Lithuanian case; personal choice; resistance; CC BY-SA License (https://creativecommons.org/licenses/by-sa/2.0)

This paper was presented at the 10th International Conference on Baltic and Nordic Studies in Romania entitled Dissent versus Conformism in the Nordic, Baltic and Black Sea Areas, “Ovidius" University of Constanţa, 6-8 June 2019.

The aim of the report is to introduce the author's point of view concerning the dilemma between dissent and conformism based on Lithuanian investigations and archival documents. The prevailing chronological frames are defined by the fifth decade of the twentieth century to the second decade of the twenty-first century. That means that preponderant materials concerning dissent and conformism are first of all directly related to the occupational Soviet regime. The report does not pretend to give a comprehensive analysis of the "Lithuanian case", though it seeks to answer the following questions:

1) Is it possible to define universal criteria for dissent and conformism investigation? Is it possible to draw a clear line between such converging meanings as resistance and dissent, dissent and conformism, conformism and obedience, conformism and surrender, conformism and betrayal, conformism and self-sacrifice? Do such dividing lines exist at all?

2) What kind of categories dissent and conformism are - legal or moral? In case their nature is legal - then first of all we should talk about obedience or disobedience according to certain legislative norms and qualify certain activities or standings in the light of law. In case their nature is moral - then it means that we are dealing with individual or collective choice between human values.

Once we agree on the treatment of these questions/answers common and acceptable for each and all only then we'll be ready for a comprehensive analysis of this problem. 
Relevance of the topic. Evidences and examples that could be qualified as classic ones concerning dissent and conformism are widely known. Already one of the earliest human written testimonies - Bible provides lots of examples when a person - let it be a prophet or just a righteous individual (man or woman) - has been persecuted for either critics against authorities, representatives of those times' ruling regime, or simply for their commitment to certain values. Another example is Socrates, the Greek philosopher (469-399 B.C.), who confessed and proclaimed ethical values, laid the foundations for so-called moral philosophy. Socrates stands for the idea that the prospect of death does not absolve the person from following the path of goodness and truth. Actually, Socrates was condemned to death because of his commitment to his beliefs and moral values.

New Testament also gives us lots of examples of dissent and conformism. John the Baptist was beheaded for his criticism against the tetrarch Herod for his personal unmoral (but not illegal!) behavior. Jesus Christ was condemned and crucified because of his teaching that contradicted to prevailing traditional one. Jesus' disciples and followers were persecuted for their beliefs.

One more widely known example is Thomas More (7 February 1478 - 6 July 1535) case. As we know, Thomas More was a person of value and beliefs: as a catholic priest he remained faithful to the Pope and refused to acknowledge the king of England Henry VIII as the Supreme Head of the Church of England; he did not welcome annulment of king's marriage to his fifth wife Catherina of Aragon and his marriage to the sixth one, Anne Boleyn. As we know, his refusal to attend the coronation of Anne Boleyn as a Queen of England was the final pretext for sentencing him to death in spite of the fact that he was friend to the king. It would have been enough to him to come to his friend's "evening party", pay respect to him and his new wife, and then to be one of the most important guests and remain friends with the most mighty person in the kingdom. In spite of all this he preferred to die, to leave his family, his loving and beloved wife and children, but to remain committed to his values. 
Search for universal criteria. Converging meanings, dividing lines. Neither Old Testament prophets, nor Jesus or his followers, nor Socrates or Thomas More called for fighting or even disobeying the ruling regime. Nevertheless, they all were sentenced.

Here in Lithuania we have rather simple and clear prevailing, but not necessarily entirely correct division lines between resistance, dissent and conformism. Most probably it developed out of Lithuanian nation experience of occupations and losing its freedom that go back at least to the end of the 18th century. Because of this occupational experience our researchers usually qualify resistance to have two levels: active resistance (usually understood as armed resistance) and passive resistance (usually understood as non-violent resistance) or dissent. In 1795, right away after Lithuania's occupation by Russian Empire an armed uprising led by general Tadeusz Kościuszko broke out; during the 19th century armed uprisings took place in Lithuania in 1831 and in 1863-1864. It means that amid unsuccessful uprisings, which each time were suppressed, there were periods that are usually qualified as passive resistance or dissent. Nevertheless, here in Lithuania both of them were directed against occupational regime and had clear independence aspirations. Later, in the middle of the 20th century, we witnessed the same story, soon after accepting the ultimatum conditions imposed by the Soviet Union on 15 June 1940 against the Lithuanian Government and the incorporation of Independent Lithuanian State within the USSR, Lithuanian liberation movement broke out. During the first Soviet Russia occupation that lasted a little more than one year (15 June 1940 - 23 June 1941) the resistance expressed itself by preparation of an armed uprising which burst out on the 23 June 1941, i.e. the day when the German troops entered the territory of the Soviet occupied Lithuania. Of course, it should be emphasized that the Lithuanian Government's position of accepting the ultimatum and urging Lithuanian residents and soldiers not to resist against incoming Red Army ${ }^{1}$ is usually qualified ambiguously: either as hesitation, cowardice,

\footnotetext{
${ }^{1}$ Laimute Breslavskienè, Lietuvos okupacija ir aneksija: 1939-1940 : dokumentu rinkinys (Vilnius: Mintis, 1993) V., 207-208, 281-283; Juozas Audenas, Paskutinis posedis; atsiminimai (New York'as: Romuva, 1966), etc.
} 
conformism or even betrayal of state and nation interests. Incidentally, similar challenges faced Czechoslovakian Government in October 1938 March 1939, Austrian Government in March 1938, Estonian and Latvian Governments - in June 1940, Romanian Government - in July 1940, etc.

With the beginning of the second Soviet occupation in July-August 1944 Lithuanian nation made a heroic attempt of armed resistance against conquering Soviet regime which lasted for nearly ten years (1944-1953). In Lithuania it is widely accepted that since 1953, when the armed resistance was suppressed, the nonviolent resistance stage of Lithuanian liberation movement started. This nonviolent resistance movement is usually called in Lithuania as passive resistance or dissent. In turn, dissent is usually used as synonym to dissidence, especially when we are talking about societies which were/are under explanation of dissent as derived from Latin dissentire which means "differ in sentiment" and defines dissent as following: „To hold or express opinions that are at variance with those commonly or officially held “. ${ }^{2}$ And what concerns the word dissidence Oxford dictionary gives us explanation as derived from Latin dissident which means "sitting apart, disagreeing" (from dis - 'apart' + sedere - 'sit') and defines dissidence as opposition to official policy. According to the Oxford dictionary, dissident is a person who opposes official policy, especially that of an authoritarian state". 3

One more remark - we should pay attention to the difference between "occupied country dissidence" and "occupant country dissidence". Dissidence in occupied countries is usually related to the aspirations of self-determination of nations. However, dissidents in Soviet Russia did not urge to overthrow or even disobey the ruling Soviet regime, did not seek to resist government or existing order. They just demanded that the authorities followed the Constitution and other legal acts. The dissidents declared that their aim is not to act against the ruling system but to improve it. Prominent Soviet Russia dissident Aleksandr Solzhenitsyn in his famous article entitled "To Live Without Lie" written in 1974 expressed

\footnotetext{
${ }^{2}$ Dissent. - Oxford Living Dictionaries. https://en.oxforddictionaries.com/definition/dissent. Accessed: 8 March 2019.

${ }^{3}$ Dissident. - Oxford Living Dictionaries. -

https://en.oxforddictionaries.com/definition/dissident. Accessed:8 March 2019.
} 
his concern that Soviet society was in danger of spiritual collapse. According to him, this collapse could not be stopped because people did not have enough strength to do it. Compulsion is strong, much stronger than dissidents are. And it may seem that there was no way out. Nevertheless, according to Solzhenitsyn, the compulsion needs lie for its existence and demands from us our obedience to lie, our individual participation in lie in our everyday life. And particularly this, according to A. Solzhenitsyn, prompts the way out. Solzhenitsyn gave an advice - let the lie prevail, let the lie rule. Nevertheless, let it exist without one's personal participation in this. Once we are afraid or just not ready to speak the truth, to speak what we are thinking in public, loudly, let us refuse to speak lie, let us refuse to speak what we do not have in our minds. According to Solzhenitsyn this should be the true and perhaps the most effective way of dissent. To refuse to support lies consciously. ${ }^{4}$ This article might be qualified as a certain moral manifesto of dissent.

Prominent Lithuanian opponent to the ruling Soviet regime Antanas Terleckas has mentioned in his memoirs that the regime tolerated their activities until they would not cross a certain line of tolerance. Everybody perceived that such a line of tolerance exists though where and what that line was nobody knew for sure. Each time it depended on a particular case and on those who had the power to make a decision. It means that both "occupied country "occupant country dissents" could have acted within a legal framework and did not exceed a certain line. And, of course, all the dissident activities were to be controlled by appropriate government structures. ${ }^{5}$ The other well-known representative of Lithuanian dissent movement Julius Sasnauskas recalls that during his interrogations a KGB interrogator used to repeat him: „We do not care what You think. We do care that You stay loyal." ${ }^{\text {6 }}$

\footnotetext{
${ }^{4}$ Aleksndras Solženycinas. Gyventi be melo. - http://www.lkbkronika.lt/index.php/ausra-nr1/905-gyventi-be-melo. Accessed: 9 March 2019.

${ }_{5}$ Antanas Terleckas, Laisves priesăušryje rezistento prisiminimai 1970-1986 (Vilnius: Lietuvos Gyventoju Genocido ir Rezistencijos Tyrimo Centras, 2011), p. 6-17.

${ }^{6}$ J. Sasnauskas, Tiesos sugrižimas? -

https://www.delfi.lt/archive/tiesos-sugrižimas.d?id=3169191. Accessed: 18 March 2019.
} 
As we can see, contrary to the active resistance movement, members who were a priori qualified as enemies to the ruling regime, the members of the dissent movement might be tolerated up to certain relatively wide limits. Definitions „dissent" and „conformism" are not included perhaps in any country's Criminal Code, thus should be evaluated and defined first of all as moral categories. That's why especially from the end of the fifties beginning of the sixties of the 20th century, when active resistance was suppressed, Lithuanian dissidents and dissents usually have been prosecuted, punished or repressed either without applying any Code, without any legal basis, only by oral order - so called "phone right from above" (for example, they were being dismissed from their jobs or studies) either applying certain articles of the Criminal Code in order to show dissidence as some kind of violation of public order and dissidents themselves as small scale criminals or simply hooligans. Or, at last, by widely using psychiatrics as an effective means against dissidents. In many cases dissidents were acknowledged as „mentally ill“ and closed in strict regime in psychiatric hospitals in order to be healed from "wrong thinking $" .{ }^{7}$ Such was the case of Romas Kalanta, who self-immolated in protest against the Soviet regime on 14 May 1972 in Kaunas Musical Theatre Park. As he had written in his diary „For my death Soviet Regime is to be blamed“. He was recognized as mentally ill by a medical psychiatric commission composed of psychiatrists loyal to the Soviet regime. The commission made the conclusion that a „,...normal person cannot be dissatisfied by the Soviet system. ${ }^{\prime 8}$

We have several diaries written by post-war active resistance movement participants that have preserved until our days. ${ }^{9}$ For example, entries of a diary, written by prominent Lithuanian post-war resistance movement member Justinas Lelešius-Grafas reveal his evaluation of

\footnotetext{
7 Look in: Vytauto Kaladès ir kitų asmenų baudžiamoji byla. - Lietuvos ypatingasis archyvas (LYA), f. K-1, ap.58, b. 47644/3; Alfonsas Svarinskas, Nepataisomasis: monsinjoro Alfonso Svarinsko atsiminimai 1 dalis (Vilnius: Versme, 2014), p. 219-222; Nepataisomasis. Vardan Dievo, Tėvynès ir Laisvés. Atsiminimai apie monisnjora Alfonsa Svarinska. 1 dalis. Kaunas, 2015, p. 157-161, etc.

${ }^{8}$ Look in: Baudžiamoji byla Nr. 20-2-036-72 dèl Romo Kalantos mirties fakto. T. 1-2. - Kauno regioninis valstybės archyvas (KRVA), f. R-1724, ap. 1, b. 33-34.

${ }^{9}$ Justinas Lelešius-Grafas, Lionginas Baliukevičius-Dzūkas. Dienoraščiai (Kaunas, 1994), etc.
} 
conformism. He reproached that Lithuanian intellectuals would wash their hands with thousands of excuses, that was, so to say, not yet the time for resistance, that active resistance is senseless and that they would devote their knowledge and efforts for the sake of their Homeland after it becomes free and so forth. ${ }^{10}$ Opposing to such a position the author preferred ,...to die, but meaningfully, to die, but not to remain a slave. "11 According to Lelešius-Grafas, the most vulnerable, the least resistant to conformism social layer are particularly the intellectuals, who would prefer to serve the occupants and renounce their Homeland in order to survive and secure their own well-being. And then, when Lithuania would eventually regain its Independence, they would start speaking loudly about their love to their Homeland, about how they had been sacrificing themselves for the sake of their Homeland despite threat and risk of being deported to Siberia or imprisoned..$^{12}$

One more well-known story in Lithuania is also from the post-war resistance period. It is about two talented poets, Kostas Kubilinskas-Kapsas and Benediktas Labenas-Kariunas. Kapsas was full of ambition to realize himself as a poet and was eager to secure his well-being. So, Kapsas made his choice: for the promise to be provided with all the conditions for his devotion to poetry and for granting his well-being he betrayed his friend, other talented poet and the Commander of Lithuanian Partisans of Dainava District Benediktas Labenas-Kariunas and tens of other partisans, active resistance members. Later Kapsas really became a well-known childrens' poetry writer. ${ }^{13}$ Other poet and resistance fighter, Bronius Krivickas, emphasized that, of course, conformism does provide more possibilities to experience less losses and sufferings. Nevertheless, according to him, it is much better to remain honourable and at any cost not to give up one's values, human dignity and beliefs. ${ }^{14}$

\footnotetext{
${ }^{10}$ Ibid., 162.

11 Ibid., 114.

12 Ibid., p. 107.

${ }^{13}$ Look in: operatyvinè byla „Kanibalai“. - LYA, f. K-1, ap. 45, b. 148; N. Gaškaitè. Dainavos štabo išdavystè. - Laisvės kovų archyvas. T.9. - Kaunas, 1993, 165-177; Lelešius-Grafas, 270308.

${ }^{14}$ B. Krivickas, Laiku griūty. Kürybos rinktinè (Vilnius, 2017), 167-169.
} 
So, what concerns conformism in Lithuania we usually operate with formal and simple definition: conformism covers and includes those, who eagerly and voluntary agreed to collaborate with the occupational regime, who took various social, political, administrative level positions in that time occupational Soviet regime and were loyal to it. In a certain sense here in Lithuania terms such as collaboration and conformism, conformism and collaboration, collaboration and betrayal acquired very similar meanings and in certain cases are used as synonyms. For example, how should be treated the daughter of a prominent political and public figure from 20-30ies of the $20^{\text {th }}$ century Lithuania who agreed to write a publication about "Soviet Paradise" to the United State newspapers in exchange for release from deportation to Siberia? ${ }^{15}$ Also, there are lots of cases when collaboration is compared to betrayal and conformism to passive obedience. On the other hand, there are discussions concerning certain cases, when, for example, certain individuals try to prove that they took a certain position not for their own welfare but for the sake of others. The question if conformism is really easier than dissent or resistance, analysis of such cases when and under what circumstances conformism should be treated as betrayal or altruistic action for the sake of others or even personal sacrifice for the sake of others might be the theme of a separate special investigation and discussion as well as graduation of dissent and conformism phenomena's variety according to different fields of activities cultural, political, social, public, etc.

\section{Conclusions:}

1) Dissent is a phenomenon which is tolerated to a certain extent. In contrast to the resistance movement members who were a priori qualified as enemies to the ruling regime, the members of dissent movement might be tolerated up to certain relatively wide limits. However, it is hardly possible to draw clear universal dividing lines between resistance and dissent, disobedience and obedience, dissent and conformism, conformism and collaboration, conformism and betrayal;

\footnotetext{
${ }^{15}$ Look in: Birutès Tursienès baudžiamoji byla. - LYA, f. 58, ap. 1, b. P-4747.
} 
2) In Lithuania like in a number of other former occupied or still occupied countries dissent and conformism were and are directly related not only to individual freedom but to nation and state independence aspirations as well;

3) Dissent and conformism phenomena are as old as the mankind is and will remain actual until the mankind exists;

4) Contrary to the resistance whose members were a priori qualified as enemies to the ruling regime, dissent and conformism are not included in any country's criminal code and should be evaluated and defined as moral categories. That's why the solution key of the dilemma between dissent and conformism is rather simple: it depends upon each of us. On our personal stand in the face of choice. Every time when confronting a certain reality each of us is making his personal choice in between dissent and conformism based on his individual stand depending on his personal commitment to certain values.

Instead of epilogue. As we see, here in Lithuania we are often used to treat the definitions dissent and conformism within the context of occupation. On the eve of regaining of Lithuania's Independence we were sure that once we become free these definitions would disappear from our public life agenda and would remain solely as scientific investigation categories. Unfortunately, the reality of life soon proved that it was a false imagination. Nowadays the phenomena of dissent and conformism do flourish and the dilemma between them is not less actual than it was decades or even centuries ago. Who knows - maybe nowadays widely spread inability to distinguish real things from fake ones, moral blindness and loss of sensitivity in liquid modernity is the price for those decades and centuries of humble obedience, lie and fear of commitment to natural human values and truth? Of course, every time it is not easy to choose in between. Nevertheless, though we hardly have universal criteria, in each case we do have the possibility of personal choice. Such a choice should be treated like an inevitable existential exam to every human generation on the whole and to each of us in particular. 


\section{References:}

\section{Primary sources:}

Audènas, Juozas. Paskutinis posedis; atsiminimai (New York'as: Romuva, 1966).

Baliukevičius Lionginas-Dzūkas, Justinas Lelešius-Grafas. Dienoraščiai (Kaunas, 1994).

Baudžiamoji byla Nr. 20-2-036-72 dèl Romo Kalantos mirties fakto. T. 1-2. Kauno regioninis valstybės archyvas (KRVA), f. R-1724, ap. 1, b. 3334.

"Kanibalai“. Operatyvinè byla. - LYA, f. K-1, ap. 45, b. 148.

Birutés Tursienés baudžiamoji byla. - LYA, f. 58, ap. 1, b. P-4747.

Vytauto Kaladès ir kitu asmenu baudžiamoji byla. - Lietuvos ypatingasis archyvas (LYA), f. K-1, ap.58, b. 47644/3.

Svarinskas, Alfonsas. Nepataisomasis: monsinjoro Alfonso Svarinsko atsiminimai 1 dalis (Vilnius: Versme, 2014).

Terleckas Antanas, Laisves priesăušryje rezistento prisiminimai 1970-1986 (Vilnius: Lietuvos Gyventoju, Genocido ir Rezistencijos Tyrimo Centras, 2011).

\section{Secondary literature:}

Breslavskienè, Laimutè. Lietuvos okupacija ir aneksija: 1939-1940 : dokumentu. rinkinys (Vilnius: Mintis, 1993).

Dissident, Oxford Living Dictionaries, https://en.oxforddictionaries.com/definition/dissident.

Dissent, Oxford Living Dictionaries, https://en.oxforddictionaries.com/definition/dissent.

Gaškaitè, Nijolè. Dainavos štabo išdavystè. - Laisvès kovų archyvas. T.9. Kaunas, 1993.

Krivickas, Bronius. Laiku griūty. Kūrybos rinktinè (Vilnius, 2017).

Nepataisomasis. Vardan Dievo, Tèrynès ir Laisves. Atsiminimai apie monisnjora Alfonsa Svarinską. 1 dalis. - Kaunas, 2015.

Sasnauskas, Julius. Tiesos sugrįzimas? https://www.delfi.lt/archive/tiesos-sugrižimas.d?id=3169191 
132 | Revista Română de Studii Baltice şi Nordice / The Romanian Journal for Baltic and Nordic Studies 11 (2)

Solženycinas, Aleksandras. Gyventi be melo, http://www.lkbkronika.lt/index.php/ausra-nr-1/905-gyventi-bemelo. 